www.nature.com $/ \mathrm{hr}$

\title{
Role of angiotensin II in plasma PAI-1 changes induced by imidapril or candesartan in hypertensive patients with metabolic syndrome
}

\author{
Roberto Fogari, Annalisa Zoppi, Amedeo Mugellini, Pamela Maffioli, Pierangelo Lazzari and Giuseppe Derosa
}

To evaluate the relationship between plasma plasminogen activator inhibitor-1 (PAI-1) and angiotensin II (Ang II) changes during treatment with imidapril and candesartan in hypertensive patients with metabolic syndrome. A total of 84 hypertensive patients with metabolic syndrome were randomized to imidapril $10 \mathrm{mg}$ or candesartan $16 \mathrm{mg}$ for 16 weeks. At weeks 4 and 8 , there was a dose titration to imidapril $20 \mathrm{mg}$ and candesartan $32 \mathrm{mg}$ in nonresponders (systolic blood pressure (SBP) $>140$ and/or diastolic blood pressure (DBP) $>90 \mathrm{~mm} \mathrm{Hg}$ ). We evaluated, at baseline and after 2, 4, 8, 12 and 16 weeks, clinic blood pressure, Ang II and PAI-1 antigen. Both imidapril and candesartan induced a similar SBP/DBP reduction ( $-19.4 / 16.8$ and $-19.5 / 16.3 \mathrm{~mm} \mathrm{Hg}$, respectively, $P<0.001$ vs. baseline). Both drugs decreased PAI-1 antigen after 4 weeks of treatment, but only the PAI-1 lowering effect of imidapril was sustained throughout the 16 weeks $\left(-9.3 \mathrm{ng} \mathrm{ml}^{-1}, P<0.01\right.$ vs. baseline), whereas candesartan increased PAl-1 (+6.5 $\mathrm{ng} \mathrm{ml}^{-1}, P<0.05$ vs. baseline and $P<0.01$ vs. imidapril). Imidapril significantly decreased Ang II levels ( $-14.6 \mathrm{pg} \mathrm{ml}^{-1}$ at week 16, $P<0.05$ vs. baseline), whereas candesartan increased them $\left(+24.2 \mathrm{pg} \mathrm{ml}^{-1}, P<0.01\right.$ vs. baseline and vs. imidapril). In both groups there was a positive correlation between Ang II and PAI-1 changes ( $r=0.61, P<0.001$ at week 16 for imidapril, and $r=0.37, P<0.005$ at week 16 for candesartan). Imidapril reduced plasma PAI-1 and Ang II levels, whereas candesartan increased them. This suggests that the different effect of angiotensin-converting enzyme inhibitors and Ang II blockers on Ang II production has a role in their different influence on fibrinolysis.

Hypertension Research (2011) 34, 1321-1326; doi:10.1038/hr.2011.137; published online 4 August 2011

Keywords: candesartan; fibrinolysis; imidapril; PAI-1

\section{INTRODUCTION}

Considerable evidence has accumulated demonstrating that the reninangiotensin system (RAS) is a key regulator of the fibrinolytic balance, mainly by inducing the expression of plasminogen activator inhibitor1 (PAI-1), a major physiological inhibitor of fibrinolysis. ${ }^{1-3}$ The main effector peptide of the RAS, angiotensin II (Ang II), stimulates PAI-1 expression in vitro in a variety of cell types, including smooth muscle cells, endothelial cells, adipocytes, astrocytes, proximal tubular epithelial cells and mesangial cells. ${ }^{4-7}$ Similarly, also in vivo studies conducted both in animal models and in humans demonstrated that Ang II induces PAI-1 expression. ${ }^{8-10}$

Blockade of the RAS by angiotensin-converting enzyme inhibitors (ACE-Is) has been generally demonstrated to reduce PAI-1 levels in both experimental and clinical studies. ${ }^{11-16}$ Contrasting results have been reported about the effects on fibrinolysis of Ang II receptor blockers (ARBs), which inhibit the RAS throughout the block of the effects of Ang II at the AT1 receptor level. ${ }^{17-22}$ Most studies showed no influence, ${ }^{17-20}$ whereas only a few studies showed a reduction in PAI-1 plasma levels with ARBs. ${ }^{21,22}$ Accordingly, most, although not all, ${ }^{23,24}$ direct comparative studies on the effects of ACE-Is and ARBs on the fibrinolytic balance observed a decrease in PAI-1 plasma levels with ACE-Is, but not with ARBs. ${ }^{25-29}$ One possible reason for such a dissimilar effect might be the different effect of the two drug classes on plasma Ang II. Unlike ACE-Is, which inhibit ACE-dependent production of Ang II, thus decreasing its plasma levels, treatment with ARBs is known to elevate markedly circulating Ang II. ${ }^{30-34}$ These effects, which occur in response to changes in physiological cascades and feedback regulations in the RAS, might partly account for the dissimilar influence of ACE-Is and ARBs on the fibrinolytic balance.

However, to the best of our knowledge, no study has specifically evaluated the possible relationship between PAI-1 and Ang II changes under treatment with ACE-Is and ARBs. With this background, the present study was undertaken in order to assess the role of Ang II in plasma PAI-1 changes induced by the ACE-I imidapril and the ARB candesartan in the treatment of hypertensive patients with metabolic syndrome. We chose this type of population as hypertension and metabolic syndrome are both characterized by impaired fibrinolysis, mainly expressed by elevated PAI-1 plasma levels ${ }^{35,36}$ and therefore 
these patients were more likely to present detectable changes in PAI-1 values under drug treatment.

\section{METHODS}

\section{Study design}

This was a 16-week prospective, randomized, open label, blinded end-point (PROBE) ${ }^{37}$ parallel group study, with two treatments arms.

\section{Study population}

Both sex consecutive outpatients, aged 18-65 years, with stage I essential hypertension (defined as sitting systolic blood pressure (SBP) $\geqslant 140 \mathrm{~mm} \mathrm{Hg}$ and $<160 \mathrm{~mm} \mathrm{Hg}$ and sitting diastolic blood pressure (DBP) $\geqslant 90 \mathrm{~mm} \mathrm{Hg}$ and $<100 \mathrm{~mm} \mathrm{Hg}$ after a 2-weeks washout placebo period) and metabolic syndrome (AHA/NHLBI criteria) ${ }^{38}$ were considered eligible to be enrolled in the study. Exclusion criteria were as follows: secondary hypertension, creatinine clearance $<80 \mathrm{ml} \mathrm{min}^{-1}$, smoking habits, history of myocardial infarction or stroke within 6 months before the study, congestive heart failure or any severe disease likely to interfere with the conduction of the study, known contraindications or intolerance to ACE-Is or ARBs.

\section{Ethics}

The study protocol was approved by the local Ethical Committee and all eligible candidates had to provide signed informed consent before enrolling in the study.

\section{Study protocol}

Following a 2 weeks placebo washout period, patients who fulfilled the inclusion criteria were randomized in a 1:1 manner to receive either imidapril $10 \mathrm{mg}$ or candesartan $16 \mathrm{mg}$ both given once daily (o.d.) in the morning (at approximately 0800 hours) for 16 weeks. After 2, 4 and 8 weeks a dose titration to imidapril $20 \mathrm{mg}$ or candesartan $32 \mathrm{mg}$ was permitted in nonresponder patients (SBP $\geqslant 140 \mathrm{~mm} \mathrm{Hg}$ and/or DBP $\geqslant 90 \mathrm{~mm} \mathrm{Hg}$ ).

All participants maintained their usual diet and level of physical activity and avoided changes in body weight throughout the study. No concomitant medication was allowed. Compliance to trial medications was evaluated by counting the number of pills returned at the time of specified clinic visits.

Clinic blood pressure (BP), PAI-1 antigen and Ang II plasma levels were evaluated at the end of the washout period and after 2, 4, 8, 12 and 16 weeks of treatment, whereas fasting plasma glucose, fasting plasma insulin, total cholesterol, high-density lipoprotein cholesterol and triglycerides were assessed at the end of the washout period and of each treatment period.

$\mathrm{BP}$ was measured with the patient in the seated position by using a standard mercury sphygmomanometer (Korotkoff I and V) with a cuff of appropriate size. Measurements were taken in the morning after the subject had rested $10 \mathrm{~min}$ in a quiet room and before daily drug intake (that is, 24-h after dosing, at trough). The average of three successive BP readings obtained at 1-min interval was recorded.

After BP measurements, venous blood was drawn from an antecubital vein for blood sampling at the same hour in the morning (approximately between 0800 and 0900 hours), as PAI-1 concentration is known to be at its peak during this period. Blood samples were collected on ice and centrifuged immediately at $0^{\circ} \mathrm{C}$ for $20 \mathrm{~min}$. All plasma or serum samples were separated and stored at $-70{ }^{\circ} \mathrm{C}$ until assay. Blood for measurements of PAI- 1 antigen was collected in Vacutainer tubes (Becton Dickinson, Meylan, France) containing $0.105 \mathrm{nmoll}^{-1}$ acidified sodium citrate and antigen level was determined by using a 2-site enzyme-linked immunosorbent assay (Biopool AB, Umea, Sweden).

Blood samples for the determination of plasma Ang II concentration were drawn from patients in supine position after $1 \mathrm{~h}$ of complete rest and were collected into prechilled $10-\mathrm{ml}$ syringes prepared with $125 \mathrm{mmol}$ EDTA and 26 mmol phenanthrolin (Merck KGaA, Darmstadt, Germany) to inhibit ACE. The samples were centrifuged for $10 \mathrm{~min}$ at $4{ }^{\circ} \mathrm{C}$ immediately after collection and plasma was stored rapidly after centrifugation at $-21^{\circ} \mathrm{C}$ and analyzed within 3 months. Plasma samples $(1 \mathrm{ml})$ were extracted with Bond Elut PH cartridges (PK 100, ICT-ASS-Chem, Analytichem, Harbor City, CA, USA) and bound angiotensin was eluted with $0.5 \mathrm{ml}$ methanol. Subsequently, plasma extracts were evaporated in a SpeedVac (SVC 100, Savant Instruments, Pvt Ltd, Hyderabad, India) for $1 \mathrm{~h}$ under reduced pressure. Immediately after purification of the samples, immunoreactive Ang II was measured by radioimmunoassay with antiserum and labelled Ang II (NEX 105, Du Pont). ${ }^{39}$ Cross-reactivity of this method is $100 \%$ for Ang II and $1.2 \%$ for Ang I. The quantification of radioactivity was performed with a gamma counter. Measurements made by this method are accurate within a range from 1.9 to $32 \mathrm{pg}$ Ang II $\mathrm{ml}^{-1}$. All determinations of immunoreactive Ang II were made in duplicate and the mean values are given. The coefficient of variation was $<5 \%$.

Blood glucose in the fasting state was measured by the glucose oxidase method (Beckman Auto-Analyzer, Fullerton, CA, USA). Plasma insulin concentrations were determined by radioimmunoassay.

\section{Statistical analysis}

All results are expressed as means \pm s.d. All data were analyzed by a split-plot method for analysis of variance; the data for PAI-1 were also analyzed for multiple comparisons by the Dunn-Sidak method for split-plot analysis of variance. For all statistical analyses a $P$-value of $<0.05$ was considered statistically significant.

\section{RESULTS}

A total of 100 patients were screened between November 2009 and September 2010. At the end of the 2 weeks placebo washout period, 84 patients were randomized to receive imidapril $10 \mathrm{mg}(n=42)$ or candesartan $16 \mathrm{mg}(n=42)$. Their main demographic and clinic characteristics are shown in Table 1. The two treatment groups were comparable in terms of age, sex, body mass index, baseline sitting BP, fasting plasma glucose, fasting plasma insulin, total cholesterol, highdensity lipoprotein cholesterol, triglycerides, creatinine clearance and duration of hypertension. Five patients withdrew after randomization, two in the imidapril group (one withdrew the informed consent, one because of hypotension) and three in the candesartan group (one withdrew the informed consent, one because of excessively high BP values and one because of hypotension). A total of 79 patients, 40 in the imidapril group and 39 in the candesartan group completed the study.

The BP results are reported in Table 2. After 16 weeks of treatment, both imidapril and candesartan significantly decreased sitting SBP ( -19.4 and $-19.5 \mathrm{~mm} \mathrm{Hg}$, respectively, both $P<0.001$ vs. baseline) and DBP $(-16.8$ and $-16.3 \mathrm{~mm} \mathrm{Hg}$, respectively, both $P<0.001 \mathrm{vs}$. baseline), with no significant differences between them. The BP

\section{Table 1 Baseline characteristics of the patients at the beginning of} the study

\begin{tabular}{|c|c|c|}
\hline Parameters & Imidapril $(\mathrm{n}=42)$ & Candesartan $(\mathrm{n}=42)$ \\
\hline Age (years) & $56.8 \pm 9.6$ & $56.6 \pm 10.1$ \\
\hline Gender (M/F) & $19 / 23$ & $20 / 22$ \\
\hline $\mathrm{BMI}\left(\mathrm{kg} \mathrm{m}^{-2}\right)$ & $27.4 \pm 1.49$ & $27.6 \pm 1.51$ \\
\hline $\mathrm{SBP}(\mathrm{mm} \mathrm{Hg})$ & $150.2 \pm 8.4$ & $150.7 \pm 8.2$ \\
\hline $\mathrm{DBP}(\mathrm{mm} \mathrm{Hg})$ & $98.6 \pm 5.2$ & $98.9 \pm 4.9$ \\
\hline FPG (mg dl $\left.{ }^{-1}\right)$ & $92.3 \pm 8.4$ & $91.8 \pm 8.1$ \\
\hline $\mathrm{FPI}\left(\mu \mid \cup \mathrm{ml}^{-1}\right)$ & $14.3 \pm 3.7$ & $14.1 \pm 3.8$ \\
\hline $\mathrm{TG}\left(\mathrm{mg} \mathrm{dl} \mathrm{d}^{-1}\right)$ & $168.5 \pm 32.4$ & $172.2 \pm 33.9$ \\
\hline HDL-C (mg dl-1) & $42.4 \pm 5.6$ & $42.1 \pm 5.3$ \\
\hline $\mathrm{TC}\left(\mathrm{mg} \mathrm{dl}^{-1}\right)$ & $191.1 \pm 13.7$ & $190.8 \pm 13.5$ \\
\hline Creatinine clearance $\left(\mathrm{ml} \mathrm{min}^{-1}\right)$ & $92.2 \pm 11.9$ & $98.9 \pm 12.1$ \\
\hline Duration of hypertension (years) & $8.5 \pm 2.8$ & $8.4 \pm 3.1$ \\
\hline
\end{tabular}

Abbreviations: BMI, body mass index; DBP, diastolic blood pressure; F, female; FPG, fasting plasma glucose; FPI, fasting plasma insulin; HDL-C: high density lipoprotein cholesterol; M, male; SBP, systolic blood pressure; TC: total cholesterol; TG, triglycerides. $P$ not significant. 
Table 2 Effect of treatment on blood pressure

\begin{tabular}{lll}
\hline Time & Imidapril $(\mathrm{n}=40)$ & Candesartan $(\mathrm{n}=39)$ \\
\hline $\begin{array}{l}\text { Seated SBP mm Hg } \\
\text { Baseline }\end{array}$ & $149.8 \pm 8.4$ & \\
Week 2 & $141.2 \pm 7.2^{* *}$ & $150.1 \pm 8.3$ \\
Week 4 & $135.3 \pm 6.7^{* * *}$ & $142.1 \pm 7.5^{* *}$ \\
Week 8 & $133.2 \pm 6.5^{* * *}$ & $134.9 \pm 6.6^{* * *}$ \\
Week 12 & $132.1 \pm 6.3^{* * *}$ & $132.4 \pm 6.4^{* * *}$ \\
Week 16 & $130.4 \pm 6.1^{* * *}$ & $131.7 \pm 6.2^{* * *}$ \\
& & $130.6 \pm 6.3^{* * *}$ \\
Seated DBP mm Hg & & \\
Baseline & $99.1 \pm 5.1$ & $98.9 \pm 4.9$ \\
Week 2 & $92.3 \pm 4.4^{* *}$ & $91.8 \pm 4.2^{* *}$ \\
Week 4 & $88.6 \pm 4.1^{* * *}$ & $88.2 \pm 3.8^{* * *}$ \\
Week 8 & $85.2 \pm 3.6^{* * *}$ & $85.5 \pm 3.4^{* * *}$ \\
Week 12 & $84.3 \pm 3.1^{* * *}$ & $84.5 \pm 3.0^{* * *}$ \\
Week 16 & $82.3 \pm 2.7^{* * *}$ & $82.6 \pm 2.8^{* * *}$
\end{tabular}

Abbreviations: DBP, diastolic blood pressure; SBP, systolic blood pressure.

${ }^{* *} P<0.01$ vs. baseline; ${ }^{* * *} P<0.001$ vs. baseline.

Table 3 Effect of treatment on metabolic parameters

\begin{tabular}{|c|c|c|}
\hline Parameters & Imidapril $(\mathrm{n}=40)$ & Candesartan $(\mathrm{n}=39)$ \\
\hline \multicolumn{3}{|c|}{$F P G\left(m g d l^{-1}\right)$} \\
\hline Baseline & $92.2 \pm 8.3$ & $91.9 \pm 8.1$ \\
\hline Week 16 & $90.8 \pm 8.2$ & $90.9 \pm 7.9$ \\
\hline \multicolumn{3}{|c|}{$F P I\left(\mu / \cup m I^{-1}\right)$} \\
\hline Baseline & $14.4 \pm 3.8$ & $14.2 \pm 3.9$ \\
\hline Week 16 & $13.8 \pm 3.5$ & $13.9 \pm 3.6$ \\
\hline \multicolumn{3}{|c|}{$T G\left(m g d l^{-1}\right)$} \\
\hline Baseline & $169.5 \pm 33.1$ & $171.4 \pm 33.7$ \\
\hline Week 16 & $159.5 \pm 31.8$ & $165.3 \pm 32.5$ \\
\hline \multicolumn{3}{|c|}{$H D L-C\left(m g d l^{-1}\right)$} \\
\hline Baseline & $42.6 \pm 5.5$ & $42.4 \pm 5.3$ \\
\hline Week 16 & $42.9 \pm 5.4$ & $42.5 \pm 5.5$ \\
\hline \multicolumn{3}{|l|}{$T C\left(m g d l^{-1}\right)$} \\
\hline Baseline & $189.8 \pm 13.6$ & $191.2 \pm 13.6$ \\
\hline Week 16 & $186.2 \pm 13.5$ & $189.9 \pm 13.7$ \\
\hline
\end{tabular}

Abbreviations: FPG, fasting plasma glucose; FPI, fasting plasma insulin; HDL-C, high-density lipoprotein cholesterol; TC, total cholesterol; TG, triglycerides.

$P$ not significant.

reduction was already evident after 2 weeks and sustained throughout the study with both treatments.

The metabolic effects are shown in Table 3. Neither imidapril nor candesartan significantly affected fasting plasma glucose, fasting plasma insulin, total cholesterol, high-density lipoprotein cholesterol and triglycerides plasma levels.

The effects of treatments on plasma PAI-1 antigen and Ang II are reported in Table 4 and Figures 1 and 2. Both imidapril and candesartan significantly decreased PAI-1 antigen after the first 2 weeks of treatment $\left(-7.4\right.$ and $-5.1 \mathrm{ng} \mathrm{ml}^{-1}$, respectively, both $P<0.05$ vs. baseline). Thereafter, only the PAI-1 lowering effect of imidapril was sustained throughout the 16 weeks period $\left(-9.3 \mathrm{ng} \mathrm{ml}^{-1}, P<0.01\right.$ vs. baseline), whereas in the candesartan group PAI-1 antigen returned to baseline values at week 4 and significantly increased at week 16 ( $+6.5 \mathrm{ng} \mathrm{ml}^{-1}, P<0.05$ vs. baseline and $P<0.01$ vs. imidapril). As shown in Figure 1, the change in PAI-1 antigen over time in response
Table 4 Effect of treatment on plasma PAI-1 antigen and Ang II

\begin{tabular}{lll}
\hline Time & Imidapril & Candesartan \\
\hline PAl-1 antigen $\left(\mathrm{ngm}^{-1}\right)$ & & \\
Baseline & $26.6 \pm 13.1$ & $26.2 \pm 13.3$ \\
Week 2 & $19.2 \pm 9.8^{*}$ & $21.1 \pm 11.1^{*}$ \\
Week 4 & $16.8 \pm 7.6^{* *}$ & $25.3 \pm 13.7$ \\
Week 8 & $18.1 \pm 8.1^{*}$ & $29.5 \pm 13.1$ \\
Week 12 & $17.5 \pm 7.4^{* *}$ & $31.9 \pm 12.6^{*}$ \\
Week 16 & $17.3 \pm 7.5^{* *}$ & $32.7 \pm 13.8^{* *}+$ \\
Ang /l (pg m/-1) & & \\
Baseline & $29.8 \pm 7.8$ & $28.9 \pm 7.2$ \\
Week 2 & $17.2 \pm 4.1^{* *}$ & $32.2 \pm 10.5^{\circ}$ \\
Week 4 & $15.5 \pm 3.7^{* *}$ & $38.4 \pm 12.3^{*+}$ \\
Week 8 & $14.7 \pm 3.5^{* *}$ & $46.7 \pm 16.4^{* *+}$ \\
Week 12 & $14.8 \pm 3.4^{* *}$ & $52.8 \pm 19.1^{* *+}$ \\
Week 16 & $15.2 \pm 3.6^{* *}$ & $53.1 \pm 20.5^{* *+}$ \\
\hline
\end{tabular}

Abbreviations: Ang II, angiotensin II; PAI-1, plasminogen activator inhibitor-1.

${ }^{*} P<0.05$ vs. baseline; ${ }^{* *} P<0.01$ vs. baseline; ${ }^{\circ} P<0.05 ;{ }^{+} P<0.01$ vs. imidapril.

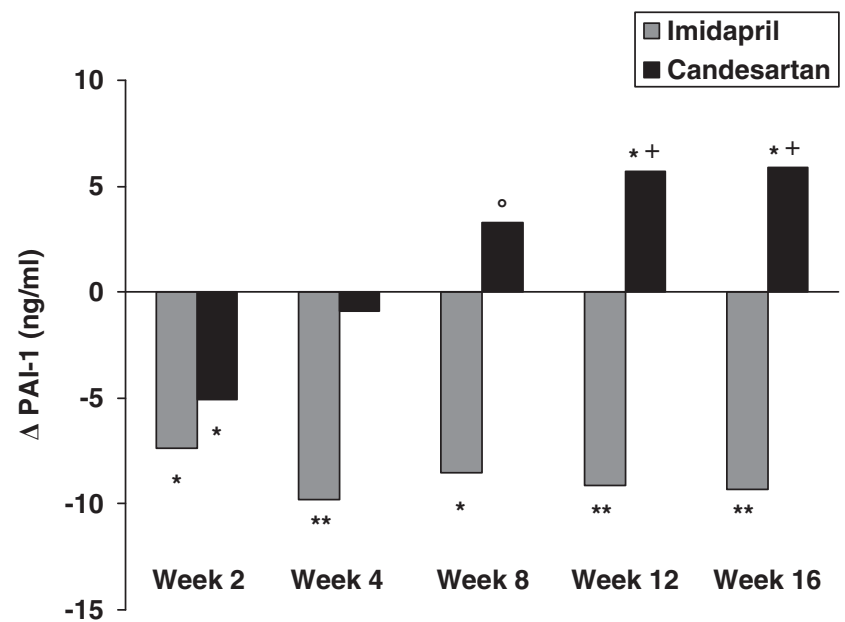

Figure 1 Plasma PAI-1 changes induced by imidapril or candesartan in hypertensive patients with metabolic syndrome. ${ }^{*} P<0.05$ vs. baseline; ${ }^{*} P<0.01$ vs. baseline; ${ }^{\circ} P<0.05$ vs. imidapril; ${ }^{+} P<0.01$ vs. imidapril. PAI-1, plasminogen activator inhibitor.

to treatment was significantly less marked during candesartan than during imidapril treatment.

Imidapril significantly decreased Ang II plasma levels; the reduction was already evident after 2 weeks $\left(-12.6 \mathrm{pg} \mathrm{ml}^{-1}, P<0.05\right.$ vs. baseline) and persisted substantially unchanged throughout the study $\left(-14.6 \mathrm{pg} \mathrm{ml}^{-1}\right.$ at week $16, P<0.05$ vs. baseline). By contrast, candesartan progressively increased Ang II values, the rise being statistically significant from week 4 ( $+9.5 \mathrm{pg} \mathrm{ml}^{-1}, P<0.05$ vs. baseline) onwards $\left(+24.2 \mathrm{pg} \mathrm{ml}^{-1}\right.$ at week $16, P<0.01$ vs. baseline and $v s$. imidapril; Figure 2). As shown in Figure 3, in the imidapril-treated patients, the Ang II changes strictly paralleled the PAI-1 changes and correlation analysis showed a highly significant relationship between the PAI-1 and the Ang II imidapril-induced decrease for the entire duration of the study ( $r=0.48, P<0.01$ at week $2 ; r=0.61, P<0.001$ at week 16 ). As shown in Figure 4 , in the candesartan-treated patients, the change in PAI-1 levels was accompanied by a parallel change in Ang II only from week 8 onwards; also in this group, a positive relationship 


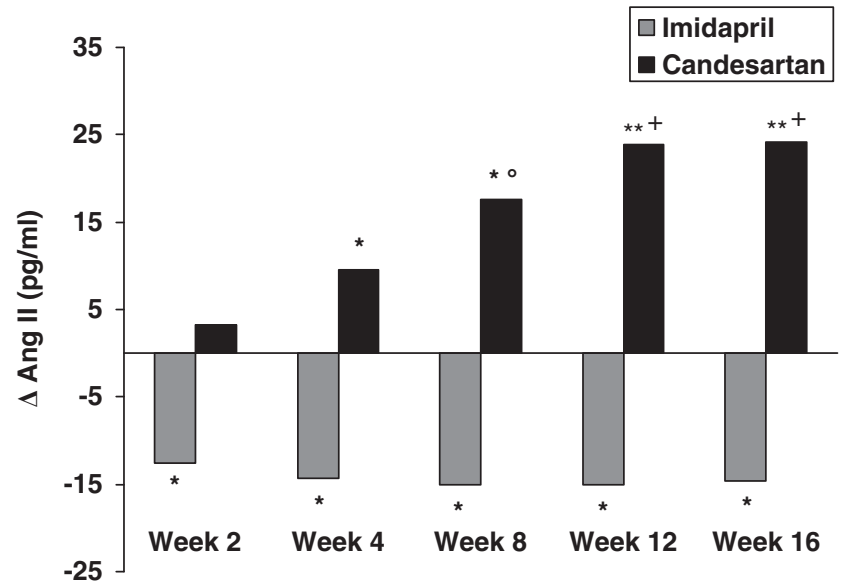

Figure 2 Plasma Ang II changes induced by imidapril or candesartan in hypertensive patients with metabolic syndrome. ${ }^{*} P<0.05$ vs. baseline; ${ }^{* *} P<0.01$ vs. baseline; ${ }^{\circ} P<0.05$ vs. imidapril; $+P<0.01$ vs. imidapril. Ang II, angiotensin II.

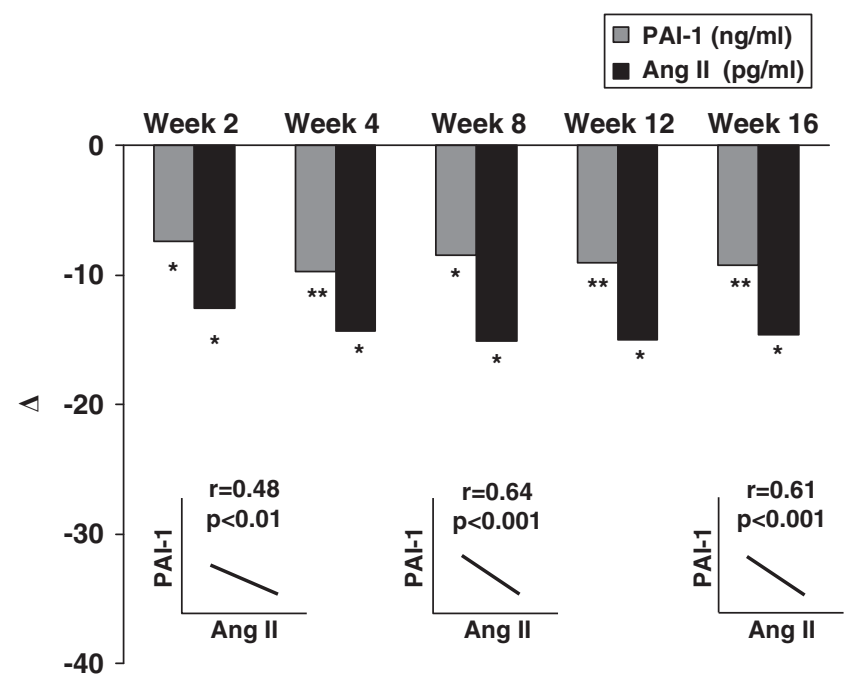

Figure 3 Relationships between plasma PAI-1 and Ang II changes during imidapril in hypertensive patients with metabolic syndrome. ${ }^{*} P<0.05$ vs. baseline; ${ }^{*} P<0.01$ vs. baseline. Ang II, angiotensin II; PAI-1, plasminogen activator inhibitor.

between PAI-1 and Ang II candesartan-induced changes was found, although the correlation analysis showed a lower level of statistical significance compared with that observed with imidapril $(r=0.27$, $P<0.05$ at week $8 ; r=0.37, P<0.005$ at week 16 ).

\section{DISCUSSION}

The findings from the present study indicated that in stage I hypertensive patients with associated metabolic syndrome, 16-week antihypertensive treatment with imidapril and candesartan, in front of equivalent antihypertensive efficacy, exerted dissimilar effects on PAI-1 antigen, whose plasma levels were significantly reduced by the ACE-I and increased by the ARB. Besides, when the effects of the two drugs

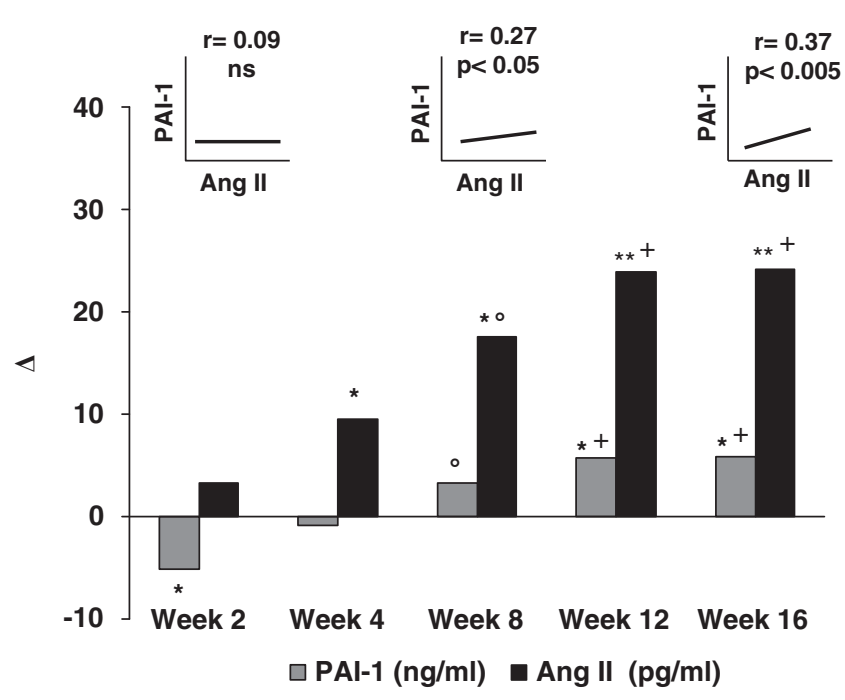

Figure 4 Relationships between plasma PAI-1 and Ang II changes induced by candesartan in hypertensive patients with metabolic syndrome. ${ }^{*} P<0.05$ vs. baseline; ${ }^{* *} P<0.01$ vs. baseline; ${ }^{\circ} P<0.05$ vs. imidapril; ${ }^{+} P<0.01$ vs. imidapril. Ang II, angiotensin II; PAI-1, plasminogen activator inhibitor.

on PAI-1 antigen over time were considered, a different time course of effects was observed. In fact, in agreement with some previous observations by ourselves and other authors, ${ }^{29,40,41}$ short-term treatment with both imidapril and candesartan decreased PAI-1 antigen plasma levels, whereas in the long-term only the ACE-I reduced PAI-1, while the ARB progressively enhanced it.

The dissimilar effect of imidapril and candesartan on PAI- 1 antigen observed in this study cannot be related to a difference in BP decrease, as the BP lowering effect was similar in the two treatment groups. Possible influence of body weight changes on the fibrinolytic system $^{42,43}$ can also be excluded, as all participants in this study maintained their usual diet and level of physical activity and no significant change in their body mass index was observed.

The main element of novelty in the present study was the significant relationship we found between the PAI-1 antigen and the plasma Ang II changes in the two treatment groups. As expected, imidapril treatment significantly reduced Ang II plasma levels, whereas candesartan enhanced them, which confirmed previously described effects of ACE-I and ARB on Ang II. ${ }^{30-34}$ Both ACE-I and ARB reduce feedback inhibition of renin release, which triggers a reactive increase in plasma renin activity. With an ACE-I such an increase results in a compensatory rise in Ang I and a reduction of Ang II plasma concentrations, due to the block of ACE-mediated conversion of Ang I to Ang II; in contrast, with an ARB the reactive rise in renin activity causes increases in Ang I, Ang II and its metabolites. ${ }^{30-34}$

Interestingly, in the imidapril group the changes in Ang II values strictly paralleled the PAI-1 antigen changes and a highly significant correlation between the Ang II and the PAI-1 decrease was observed for the entire duration of the study. This suggests that the reduction of circulating Ang II has a major role in the imidapril-induced PAI-1 antigen decrease. In the candesartan group, a positive correlation between Ang II and PAI-1 changes was observed from 8 weeks onwards, when both PAI-1 and much more Ang II plasma levels increased, although the degree of statistical significance of such a correlation was lower as compared with that found in the imidapriltreated patients. These findings are in agreement with the hypothesis 
that Ang II may increase PAI-1 synthesis not only through AT1 receptors, but also through its hexapeptide catabolite, Ang IV, which binds to specific AT4 receptors. ${ }^{44,45}$ Removal of the aminoterminal amino acid from Ang II by an aspartate amino peptidase yields Ang III (called also angiotensin(2-8); removal of the terminal arginine from Ang III by ACE2 yields Ang IV (called also angiotensin-2(3-8)). Although the reduction of Ang II levels by the ACE-I, limiting the conversion of Ang II to smaller peptides, may prevent the endothelial synthesis of PAI-1, the reactive rise of Ang II because of AT1 blockade might lead to increased Ang IV production and thus favor PAI-1 expression via endothelial AT4 receptor stimulation. ${ }^{44,45}$

Upregulation of the AT4 receptors after 2 weeks of AT1 blockade might be one possible explanation for the reduction of PAI-1 observed with short-term therapy with candesartan. ${ }^{46}$ Our observation that AT1 receptor blockade requires some weeks to produce the maximal Ang II increase also suggests that in this period of time the effect of AT1 blockade prevails on that of AT4 stimulation. The different time courses of imidapril and candesartan on PAI-1 levels might also have depended on the different duration of suppression of tissue Ang II, which is suppressed by ACE-I and not suppressed by ARB. ${ }^{47}$

Whatever the mechanisms, the different influence of ACE-I and $\mathrm{ARB}$ on the fibrinolytic balance might at least partly explain the different coronary heart disease preventive effect between the two drug classes. ${ }^{48}$ Analyses by the Blood Pressure Lowering Treatment Trialists' Collaboration have shown that for ACE-I, but not for ARB, there is evidence of BP independent effect on the risk of major coronary events. ${ }^{48}$ ACE-I, besides decreasing the release of Ang II-mediated PAI-1, may favorably alter the fibrinolytic balance also by increasing the endothelial release of bradykinin-induced tissue plasminogen activator (tPA). ${ }^{2,49,50}$ Although in the present study we did not evaluate changes in TPA levels, data from previous studies by ourselves and other authors indicated that ARB, which do not affect the metabolism of bradykinin, do not influence or even decrease plasma tPA. ${ }^{1,25,28,29}$ Coronary release of tPA from the endothelium is an important defense against coronary heart disease. The recently published results of the Shiga Plasminogen Activator In Coronary Circulation study ${ }^{51}$ have demonstrated that ACE inhibition increased coronary release of tPA, although only in women. Such a positive effect of ACE-I on the coronary fibrinolytic balance might contribute to the reduction in coronary events observed with these drugs.

Differently from these authors, we did not observe any differences between sex regarding our data.

\section{CONCLUSIONS}

The results of the present study indicated that in the treatment of hypertensive patients with metabolic syndrome, the ACE-I imidapril and the ARB candesartan, despite equivalent antihypertensive efficacy, exerted dissimilar effects on PAI-1 plasma levels, which were reduced by imidapril and increased by candesartan. Such changes appeared to be related to plasma Ang II changes, which suggests that the different effect that ACE-I and ARB exert on Ang II production has a role in their different influence on fibrinolysis.

\section{CONFLICT OF INTEREST}

The authors declare no conflict of interest.

\section{ACKNOWLEDGEMENTS}

We certify that we have no affiliation with, or financial involvement in, any organization or entity with a direct financial interest in the subject matter or materials discussed in the manuscript.
1 Brown NJ, Agirbasli MA, Williams GH, Litchfield WR, Vaughan DE. Effect of activation and inhibition of the renin-angiotensin system on plasma PAI-1. Hypertension 1998; 32: 965-971.

2 Vaughan DE. Angiotensin, fibrinolysis and vascular homeostasis. Am J Cardiol 2001; 87: 18C-24C.

3 Ferrario CM, Strawn WB. Role of the renin-angiotensin-aldosterone system and pro-inflammatory mediators in cardiovascular disease. Am J Cardiol 2006; 98: 121-128.

4 Feener EP, Northrup JM, Aiello LP, King GL. Angiotensin II regulates the expression of plasminogen activator inhibitor-1 in cultured endothelial cells. J Clin Invest 1995; 95 : 995-1001.

5 Gesualdo L, Ranieri E, Monno R, Rossiello MR, Colucci M, Semeraro N, Grandaliano G, Schena FP, Ursi M, Cerullo G. Angiotensin IV stimulates plasminogen activator inhibitor-1 expression in proximal tubular epithelial cells. Kidney Int 1999; 56: 461-470.

6 Skurk T, Lee YM, Hauner H. Angiotensin II and its metabolites stimulate PAI-1 protein release from human adipocytes in primary culture. Hypertension 2001; 37: 1336-1340.

7 Fintha A, Sebe A, Masszi A, Terebessy T, Huszar T, Rosivall L, Mucsi I. Angiotensin II activates plasminogen activator inhibitor-1 promoter in renal tubular epithelial cells via the AT1 receptor. Acta Physiol Hung 2007; 94: 19-30.

8 Ridker PM, Gaboury CL, Conlin PR, Seely EW, Williams GH, Vaughan DE. Stimulation of plasminogen activator inhibitor in vivo by infusion of angiotensin II: evidence of a potential interaction between the renin-angiotensin-system and fibrinolytic function. Circulation 1993; 87: 1969-1973.

9 Abrahamsen CT, Pullen MA, Schnackenberg CG, Grygielko ET, Edwards RM, Laping NJ, Brooks DP. Effects of angiotensin II and IV on blood pressure, renal function and PAI-1 expression in the heart and the kidney of the rat. Pharmacology 2002; 66: 26-30.

10 Brown NJ, Bradford J, Wang Z, Lea W, Ma L, Ma J, Vaughan DE, Fogo AB. Modulation of angiotensin II and norepinephrine-induced plasminogen activator inhibitor-1 expression by AT1a receptor deficiency. Kidney Int 2007; 72: 72-81.

11 Wright RA, Flapan AD, Alberti KG, Ludlam CA, Fox KA. Effects of captopril therapy on endogenous fibrinolysis in men with recent, uncomplicated, myocardial infarction. J Am Coll Cardiol 1994; 24: 67-73.

12 Vaughan DE, Roleau JL, Ridker PM, Arnold JM, Menapace FJ, Pfeffer MA. Effects of ramipril on plasma fibrinolytic balance in patients with acute anterior myocardial infarction: HEART Study Investigators. Circulation 1997; 96: 442-447.

13 Soejima H, Ogawa H, Yasue H, Suefuji H, Kaikita K, Nishiyama K. Effects of imidapril therapy on endogenous fibrinolysis in patients with recent myocardial infarction. Clin Cardiol 1997; 20: 441-445.

14 Sakata K, Shirotani M, Yoshida H, Urano T, Takada A. Differential effects of enalapril and nitrendipine on the fibrinolytic system in essential hypertension. Am Heart J 1999; 137: 1094-1099.

15 Lottermoser K, Wostmann B, Weisser B, Hertfelder HJ, Schmitz U, Vetter H, Dusing R. Effects of captopril on fibrinolytic function in healthy humans. Eur J Med Res 1999; 4: 31-34.

16 Fogari R, Preti P, Lazzari P, Corradi L, Zoppi A, Fogari E, Mugellini A. Effect of benazepril amlodipine combination on fibrinolysis in hypertensive diabetic patients. Eur J Clin Pharmacol 2003; 59: 271-275.

17 Seljeflot I, Moan A, Kjeldsen S, Sandvik E, Arnesen H. Effect of angiotensin II receptor blockade on fibrinolysis during acute hyperinsulinemia in patients with essential hypertension. Hypertension 1996; 27: 1299-1304.

18 Fogari R, Zoppi A, Malamani G, Marasi G, Pesce RM, Banderali A, Mugellini A. Effects of four angiotensin II-receptor antagonists on fibrinolysis in post-menopausal women with hypertension. Curr Ther Res 2001; 62: 68-78.

19 Skurk T, Lee YM, Nicuta-Rolfs TO, Haastert B, Wirth A, Hauner H. Effect of the angiotensin II receptor blocker candesartan on fibrinolysis in patients with mild hypertension. Diabetes Obes Metab 2004; 6: 56-62.

20 Lin TH, Voon WC, Yen HW, Huang CH, Su HM, Lai WT, Sheu SH. Lercanidipine and losartan effects on blood pressure and fibrinolytic parameters. Kaohsiung J Med Sci 2006; 22: 177-183.

21 Lottermoser $\mathrm{K}$, Hertfelder $\mathrm{HH}$, Vetter $\mathrm{H}$, Dusing R. Fibrinolytic function in diureticinduced volume depletion. Am J Hypertens 2000; 13: 359-363.

22 Liu L, Zhao SP, Zhou HN, Li QZ, Li JX. Effect of fluvastatin and valsartan, alone and in combination, on post-prandial vascular inflammation and fibrinolytic activity in patients with essential hypertension. J Cardiovasc Pharmacol 2007; 50: 50-55.

23 Goodfield NE, Newby DE, Ludlam CA, Flapam AD. Effects of acute angiotensin II type 1 receptor antagonism and angiotensin converting enzyme inhibition on plasma fibrinolytic parameters in patients with heart failure. Circulation 1999; 99: 2983-2985.

24 Hirschl MM, Bur A, Woisetschlaeger C, Derhaschnig U, Laggner AN. Effects of candesartan and lisinopril on the fibrinolytic system in hypertensive patients. J Clin Hypertens 2007; 9: 430-435.

25 Brown NJ, Agirbasli M, Vaughan DE. Comparative effect of angiotensin converting enzyme inhibition and angiotensin II type 1 receptor antagonism on plasma fibrinolytic balance in humans. Hypertension 1999; 34: 285-290.

26 Fogari R, Zoppi A, Preti P, Fogari E, Malamani G, Mugellini A. Differential effects of ACE-inhibition and angiotensin II antagonism on fibrinolysis and insulin sensitività in hypertensive post-menopausal women. Am J Hypertens 2001; 14: 921-926.

27 Fogari R, Mugellini A, Zoppi A, Corradi L, Preti P, Lazzari P, Derosa G. Losartan and perindopril effects on plasma plasminogen activator inhibitor- 1 and fibrinogen in hypertensive type 2 diabetics. Am J Hypertens 2002; 15: 316-320. 
28 Paterna S, Di Garbo V, Avellone G, Di Pasquale P, Cacia A, Tuttolomondo A, Folloone G, Cardinale A, Maniscalchi T, Licata G. Effects of losartan and delapril on the fibrinolytic system in patients with mild to moderate hypertension. Clin Drug Invest 2003; 23. 717-724.

29 Fogari R, Zoppi A, Salvadeo SA, Mugellini A, Lazzari P, Santoro T, Derosa G. Fibrinolysis and insulin sensitivity in imidapril and candesartan (FISIC study) recipients with hypertension. Hypertens Res 2011; 34: 509-515.

30 Hubner R, Hogemann AM, Sunzel M, Riddel JG. Pharmacokinetics of candesartan after single and repeated doses of candesartan cilexetil in young and elderly healthy volunteers. J Hum Hypertens 1997; 11: S19-S25.

31 Johnston $\mathrm{Cl}$, Naitoh M, Burrell LM. Rationale and pharmacology of angiotensin II receptor antagonists: current status and future issues. J Hypertens 1997; 15: S3-S8.

32 Bindschedler M, Degen P, Flesch G, De Gasparo M, Preiswerk G. Pharmacokinetic and pharmacodynamic interaction of single oral doses of valsartan and furosemide. Eur $J$ Clin Pharmacol 1997; 52: 371-378.

33 Shibasaki Y, Masaki H, Nishiue T, Nishikawa M, Matsubara H, Iwasaka T. Angiotensin II type 1 receptor antagonist, losartan, causes regression of left ventricular hypertrophy in end-stage renal disease. Nephron 2002; 90: 256-261.

34 Gradman AH, Pinto R, Kad R. Current concepts: renin inhibition in the treatment of hypertension. Curr Opin Pharmacol 2008; 8: 120-126.

35 Poli KA, Tofler GH, Larson MG, Evans JC, Sutherland PA, Lipinska I, Mittleman MA, Muller JE, D'Agostino RB, Wilson PW, Levy D. Association of BP with fibrinoIytic potential in the Framingham Offspring Population. Circulation 2000; 101: 264-269.

36 Juan Vague I, Alessi MC. PAI-1, obesity, insulin resistance and risk of cardiovascular events. Thromb Haemost 1997; 78: 656-660.

37 Hansson L, Hedner T, Dahlof B. Prospective, randomized, open label, blinded end-point (PROBE) study: a novel design for intervention trials. Blood Press 1992; 1: $113-114$

38 Grundy SM, Cleeman JI, Daniels SR, Donato KA, Eckel RH, Franklin BA, Gordon DJ, Krauss RM, Savage PJ, Smith Jr SC, Spertus JA. Diagnosis and management of the metabolic syndrome: an American Heart Association/National Heart, Lung and Blood Institute Scientific Statement. Circulation 2005; 112: 2735-2752.

39 Schmieder RE, Langenfeld MRW, Friedrich A, Schobel HP, Gatzka CD, Weihprecht H. Angiotensin II related to sodium excretion modulates left ventricular structure in human essential hypertension. Circulation 1996; 94: 1304-1309.
40 Brown NJ, Kumar S, Painter CA, Vaughan DE. Ace inhibition versus angiotensin type 1 receptor antagonism. Differential effects on PAI-1 over time. Hypertension 2002; 40: 859-865.

41 Fogari R, Zoppi A, Mugellini A, Lazzari P, Derosa G. Different effects of aliskiren and losartan on fibrinolysis and insulin sensitivity in hypertensive patients with metabolic syndrome. Horm Metab Res 2010; 42: 892-896.

42 Folsom AR, Quamhieh DT, Wing RR, Jeffrey RW, Stinson VL, Kuller LH, Wu KK. Impact of weight loss on plasminogen activator inhibitor (PAI-1), factor VII and other hemostatic factors in moderately overweight adults. Arterioscler Thromb Vasc Biol 1993; 13: 162-169.

43 Mertens I, Van Gaal LF. Obesity, haemostasis and the fibrinolytic system. Obes Rev 2002; 3: 85-101.

44 Kerins DM, Hao Q, Vaughan DE. Angiotensin induction of PAI-1 expression in endothelial cells is mediated by the hexapeptide angiotensin IV. J Clin Invest 1995; 96: 2515-2520.

45 Numaguchi Y, Ishii M, Kubota R, Morita Y, Yamamoto K, Matsushita T, Okumura K, Murohara T. Ablation of angiotensin IV receptor attenuates hypofibrinolysis via PAI-1 downregulation and reduces occlusive arterial thrombosis. Arterioscler Thromb Vasc Biol 2009; 29: 2012-2018.

46 Moeller I, Clune EF, Fennessy PA, Bingley JA, Albiston AL, Mendelsohn FA, Chai SY. Up-regulation of AT4 receptor levels in carotid arteries following balloon injury. Regul Pept 1999; 83: 25-30.

47 Johnston $\mathrm{Cl}$. Angiotensin converting enzyme inhibitors. In Nicholls MG, Robertson JIS (eds), The Renin-Angiotensin System. London, Gower, 1993, pp 87.1-87.15.

48 Blood Pressure Lowering Treatment Trialists' Collaboration.. Blood pressure-dependent and independent effects of agents that inhibit the renin-angiotensin system. J Hypertens 2007; 25: 951-958.

49 Minai K, Matsumoto T, Horie H, Ohira N, Takashima H, Yokohama H, Kinoshita M. Bradykinin stimulates the release of tissue plasminogen activator in human coronary circulation: effects of angiotensin converting enzyme inhibitors. J Am Coll Cardiol 2001; 37: 1565-1570.

50 Pretorius M, Rosenbaum D, Vaughan DE, Brown NJ. Angiotensin converting enzyme inhibition increases human vascular tissue plasminogen activator release through endogenous bradykinin. Circulation 2003; 107: 579-585.

51 Matsumoto T, Takashima H, Nakae I, Yamane T, Hayashi H, Horie M. Angiotensinconverting enzyme inhibition augments coronary release of tissue plasminogen activator in women but not in men. Hypertension 2010; 56: 364-368. 